\title{
Middle East Studies for the New Millennium: Infrastructures for Knowledge
}

\author{
Seteney Shami \& Cynthia Miller-Idriss, eds. \\ New York: New York University Press, 2016. 487 pages.
}

Middle East Studies for the New Millennium sheds light on the trials and tribulations of Middle East area studies in the highly charged and politicized context of American academia and broader US policy. In this respect, it is an important exposition of how American universities produce knowledge about different world regions (ix).

The study is the outcome of a research project that spanned a period of nearly fifteen years since 2000 . The introductory chapter, by book editors Shami and Miller-Idriss and titled "The Many Crises of Middle East Studies" (MES), refers to the contextual status of the field and relates its 'crises' to an American setting in which knowledge and power are intrinsically, even if not always clearly, juxtaposed. Shami and Miller-Idriss point out that three main institutional actors define the politics of the field: universities, federal government, and private philanthropic foundations (8). The role of the US federal government in producing knowledge, the relationship between knowledge and power, and ways of knowing about 'other' cultures and places has long been a source and subject of numerous debates and controversies (1), but the authors problematize it in terms of the "securitization of academic knowledge in the name of 'national interest,' the challenges arising out of the possibilities of unbounded, transnational fields of scholarship and the future of the university as an institution" (2). The MES also faced an additional crisis as a growing number of social scientists came to perceive it as too focused on in-depth studying of areas instead of seeking to produce knowledge based on universal theories or explanations. MES, thus, increasingly occupied a diminishing space in social sciences in favor of a humanistic turn toward cultural and linguistic approaches (9). This, according to Shami and Miller-Idriss was not simply a matter of intellectual skepticism, but rather a reflection of deliberate attempts at siphoning social scientists from universities, narrowing knowledge to specific agenda-settings, and limiting space for alternative perspectives. Due to the perceived 'anti-Americanism' of MES, in good measure emanating from claims about Edward Said's "pernicious influence," the field has increasingly 
come under siege through federal monitoring, campus watch, scrutiny of scholars exchanges, and funding restrictions (10).

Problematizing the context of MES in such terms helps frame the approach of this study around three main themes that comprise the three parts of the book and its eleven chapters. These include the relationship between MES and other social science disciplines, reconfigurations, and new emphases in MES focusing on university restructuring, language training and scholarly trends, and the politics of knowledge as they relate specifically to the many crises in the Middle East (11).

Part I, titled "Disciplines and its Boundaries," comprises four chapters, which highlight the interdisciplinary nature of area studies as a subfield within the entire "problem-solving" structure of social sciences. This tendency distinguished area studies from earlier Orientalist/civilizational scholarly traditions. The four chapters in Part I cover the relationship between area studies and political science (Lisa Wedeen), sociology (Reshat Kasaba), economics (Karen Pfeifer), and geography (Amy Mills and Timur Hammond). Together, they demonstrate how the privileged discipline or "prestige area" for theorizing reflects a different relationship with area studies depending on the discipline's definition of the "universal" (11). Wedeen challenges positivist/methodological claims about the separation of fact and value, and the unification of liberalism and science in such a fashion as to render the subfield of American studies a standard universal "nonarea", reflecting American exceptionalism (12). Kasaba examines the historically cyclical relationship between sociology and area studies "as a push-and-pull reaction to particular political imperatives," related to how social sciences and American foreign policy have been intertwined since WWII (12). Pfeifer focuses on how international financial institutions have shaped much of western economists' approaches to the Middle East region, entrenching neoclassical economic ideas associated with stabilization, liberalization, and privatization (13). Mills and Hammond examine the "spatial turn" in area studies, and how spatial methodologies have provided for a means to understand the broad socio-economic and political dynamics that have served to shape the Middle East. They point also to the interdisciplinary nature of spatial studies that could very well transform area studies by linking the region to its global context (14-15).

Part II, titled "Middle East Studies and the University," comprises four chapters by Jonathan Z. Friedman and Cynthia Miller-Idriss, Elizabeth Anderson Worden and Jeremy M. Browne, Laura Bier, and Charles Kurzman and Carl W. Ernst. These chapters highlight how knowledge about the 
Middle East are produced through changing institutional structures and architectures, particularly in relation to the rise of "the global" as a major organizational form within American universities. They also focus on the "capacities" needed to produce a new generation of qualified specialists capable of dealing with profound regional changes that would also require different policy and educational approaches (15). Friedman and Miller-Idriss look at the Hagop Kevorkian Center for Near Eastern Studies at New York University (NYU) in order to investigate how area studies centers as well as universities are to transform themselves into global institutions. They point to two separate but coexisting logics of internationalization: that of the specialist with deeper knowledge of the area, and the cosmopolitan who emphasizes breadth in global experience in order to produce the 'global citizen' (15-16). Worden and Browne focus on reasons why it was difficult for American institutions to produce proficient Arabic language speakers in significant numbers. They offer an explanation in terms of structural and cultural factors related to time constraints that graduate students face in order to learn the language, the relative lower status of language instructors, the devaluation of language learning by some social sciences disciplines, and, for all practical purposes, the difficulty of learning Arabic. Bier analyzes $\mathrm{PhD}$ dissertations concerned with the Middle East across six social sciences disciplines (political science, sociology, anthropology, economics, history and MES) during the period 2000-2010, focusing on their themes, topics and methods (253). She points out that neoliberalism and what is termed the 'Washington Consensus' have come to dominate political science, sociology and economics, while issues of identity, gender, colonialism, the nation, and Islam dominate in anthropology, history, and MES. Kurzman and Ernst go beyond Bier's thematic approach to highlight the renewed and significant institutional growth of interest in Islamic studies for national security concerns. They point as well to the encouragement offered by a number of universities to promote cross-regional approaches, not constrained by narrower definitions of distinct regions, although they also raise the problem of lack of adequate federal funding for such purposes.

Part III, titled "the Politics of Knowledge," comprises three chapters by Seteney Sami and Marcial Godoy-Anativia, Ussama Makdisi, and Irene Gendzier; and an 'Afterward' by Lisa Anderson. These chapters examine not only the production of knowledge but also how knowledge is frequently silenced by forces that "structure and restrict freedom of speech, censorship and self-censorship"-the so-called "chilling effects" (19). Sami and 
Godoy-Anativia examine the themes of campus watch or surveillance and public criticism of MES, especially after the 9/11 events of 2001, and their impact on academia and "institutional architectures" as knowledge is securitized and "privatized" (19). Makdisi and Gendzier question how American scholarship about the region has changed over time, yet almost always highly charged and politicized in large measure due to the Arab-Zionist/ Israeli conflict (20-21). Despite moves toward more critical and postnationalist approaches, Makdisi emphasizes that overall academic freedom has nevertheless been curtailed. Genzier, in turn, points to how "ignorance has [come to have] strategic value," as "caricatured images" pass for analysis (21-22). Finally, given the securitization and other intimidating measures undertaken around campuses and universities, Anderson concludes that the state of a "beleaguered" (442) MES is deplorable, describing it as "demoralized, lacking academic freedom and reliable research data, and function in a general climate of repression, neglect and isolation" (22, 442).

This important book-with extensive bibliographies in each chapter and its detailed exploration of the state of the field of United States MES in the twenty-first century-stands as a reference source for all interested in Middle East studies. "Infrastructures for Knowledge" could have made for a provocative main title of this work, in reference to the production of knowledge on the Middle East and the reproduction of new generations of Middle Eastern specialists. Its most salient aspect is that it highlights and underscores the formal and informal authoritarian and securitization measures adopted by US federal agencies as well as universities to set effective restrictions on what can or cannot be said and/or taught about MES, both in academic institutions and in the media. In addition to the proliferation of both private and public watchdogs monitoring how MES is being taught on campuses, the establishment since 2003 of twelve Homeland Security Centers of Excellence at six universities (with grants totaling about 100 million dollars) is indicative of the scale of intrusive measures (101). The broader problem is that such infringements do not take place only in US universities. Given that county's totalizing and vested interests in influencing how knowledge is produced and consumed globally, not least in and about the Middle East, the extent of its hegemonic control in that region can only be surmised.

Amr G.E. Sabet Department of Political Science Dalarna University, Falun, Sweden 